Jurnal SOSIO DIALEKTIKA 6 (2) (2021)

P-ISSN: 2540.8941 e-ISSN: 2623.2944

e-mail; sosiodialektika@unwahas.ac.id

doi; http://dx.doi.org/10.31942/sd.v6i2.5680
Dinamika Pertumbuhan Feminisme Di China Dalam Perspektif Konstruktivisme

\title{
Dinamika Pertumbuhan Feminisme Di China Dalam Perspektif Konstruktivisme
}

\author{
Anna Yulia Hartati ${ }^{1,2}$, Ismiyatun ${ }^{3}$, Adi Joko Purwanto ${ }^{4}$, Nur Islamiati ${ }^{5}$ \\ Mahasiswa Doktor Ilmu Sosial Universitas Diponegoro ${ }^{1}$, Dosen \\ Hubungan Internasional Universitas Wahid Hasyim ${ }^{2,3,4}$, Mahasiswa \\ Hubungan Internasional Universitas Wahid Hasyim ${ }^{5}$ \\ Email: annayulia@unwahas.ac.id
}

\begin{abstract}
This article describes how the growth process of feminism in China in the perspective of constructivism regarding the life-cycle of norms. In theory, there are three stages of how a norm which in this case is feminism through the life-cycle of norms. This research method uses a qualitative method of literature study. In this article, the findings are that there are three propositions related to the emergence of international norms in feminism in China, the first is Norm emergence which is described by the emergence of one of the famous female figures, namely, He Zhen, who adopted western feminism by not leaving Chinese cultural identity which was considered good for her. Chinese women's social change. In contrast to other reformers, He Zhen specifically separates the case of feminism from nationalism, stating that women's liberation is not for the sake of the nation, but rather a moral necessity. Second, the Norm Cascade is illustrated by the influence of China's state ratification of the Convention Elimination of All Forms of Discrimination against Women (CEDAW) held in Copenhagen Denmark, by accepting international norms on gender equality which in turn will require domestic laws to make some changes to suit the issue. Third, Internalization is described by the growth process of Chinese feminism, namely the process of fusion with culture within the body of feminism itself, or in other words, feminism that develops has its own unique characteristics that are not owned by other countries and only China has it.
\end{abstract}

Keywords: Chinese feminism, constructivism perspective, the lifecycle of norms

\section{A. PENDAHULUAN}

Permasalahan kesetaraan antara laki-laki dan perempuan di era modern ini bukanlah suatu tantangan yang asing lagi bagi negara-negara baik itu maju maupun berkembang. China menjadi salah satu negara yang menghadapi tantangan serupa.(Croll, 2013) Dalam menangani kasus semacam ini banyak 
Jurnal SOSIO DIALEKTIKA 6 (2) (2021)

P-ISSN: 2540.8941 e-ISSN: 2623.2944

e-mail; sosiodialektika@unwahas.ac.id

doi; http://dx.doi.org/10.31942/sd.v6i2.5680
Dinamika Pertumbuhan Feminisme Di China Dalam Perspektif Konstruktivisme

gerakan yang berlandaskan pemikiran atau ide-ide feminisme yang berupaya untuk menuntut persamaan gender di dalam masyarakat baik itu pemerintah dan non-pemerintah. Masalah ketidaksetaraan bukanlah masalah mudah yang bisa diabaikan begitu saja, karena akan ada dampak yang sangat besar dibalik itu semua.

Feminisme sendiri adalah serangkaian pemikiran yang mengakui secara eksplisit bahwa perempuan tersubordinasi oleh laki-laki dan berusaha mencari jalan keluar untuk mengatasi masalah tersebut. Feminisme juga merupakan sebuah gerakan budaya dan gerakan politik yang ingin mengubah cara berfikir perempuan serta mengubah hubungan antara perempuan dan laki-laki didalam keluarga maupun masyarakat. Asumsi utama dari feminisme ialah bahwa kondisi perempuan, pembagian peran laki-laki perempuan dalam masyarakat, adalah bentukan masyarakat, bukan sesuatu yang alami sehingga pada prinsipnya dapat diubah(Bryson, 2019)

Budaya partiarki yang sudah mendarah daging dalam masyarakat China sendiri telah mengakibatkan banyak sekali ketidakseimbangan hubungan antara laki-laki dan perempuan dalam kehidupan sosial masyarakat. Sistem sosial patriarki menjadikan laki-laki memiliki hak istimewa terhadap perempuan. Dominasi mereka tidak hanya mencakup ranah personal saja, melainkan juga dalam ranah yang lebih luas seperti partisipasi politik, pendidikan, ekonomi, sosial, hukum dan lain-lain. Budaya yang telah banyak dianut oleh masyarakat China ini juga ikut memperparah ketimpangan gender yang ada. Di China pada awalnya feminisme adalah sebuah gagasan atau ide yang datang dari barat yang dibawa oleh para missionaris dan kaum intelektual China pada masa perang candu (Opium war). Peristiwa perang candu (Opium War) pada tahun 1841 telah membuat China membuka pintu bagi kebudayaan lain untuk masuk pertama kalinya. Setelah perang candu (Opium war) berakhir, budaya barat, termasuk feminisme mulai mengalir masuk kedalam China melalui pengaruh missionaries barat.(J. Zheng, 2016) Masuknya pemikiran-pemikiran luar banyak menjadikan intelektual China 
Jurnal SOSIO DIALEKTIKA 6 (2) (2021)

P-ISSN: 2540.8941 e-ISSN: 2623.2944

e-mail; sosiodialektika@unwahas.ac.id

doi; http://dx.doi.org/10.31942/sd.v6i2.5680
Dinamika Pertumbuhan Feminisme Di China Dalam Perspektif Konstruktivisme

merasa prihatin atas fenomena sosial yang menurut mereka itu tidak benar dalam tatanan masyarakat China.

Berbagai tokoh pembaharu muncul pada era terakhir Dinasti Qing. Salah satu tokoh perempuan paling termahsyur ialah He Yi Zhen atau yang lebih dikenal sebagai He Zhen. Pandangan kritis He Zhen terhadap isu perempuan bisa dibilang memiliki pemikiran radikal pada masanya. He zhen menilai aturan ini ditandai oleh pembedaan kelas dimana hanya laki-laki saja yang menggunakan hak kepemilikan pribadi, hal itu yang menyebabkan perempuan memiliki peran yang sangat minim baik itu dalam keluarga maupun sosial, atau dalam artian yang lebih kasar adalah perempuan merupakan salah satu dari „hak milikeepribadi serang laki-laki. Menurutnya cara untuk memperbaiki masalah tersebut ialah, pertama-tama harus dihapuskannya aturan yang menitikberatkan kepada kaum laki-laki dan memperkenalkan kesetraan antara sesama manusia, yang berarti bahwa dunia harus sama-sama dimiliki oleh laki-laki maupun perempuan. Tujuan kesetaraan tersebut tidak akan tercapai kecuali melalui pembebasan perempuan.(Xiaoqi, 1991)

Bersama gerakan nasionalis, He Zhen membentuk kerjasama guna mewujudkan keseteraan yang ia maksudkan tersebut. Pembebasan perempuan merupakan salah satu cara untuk membebaskan negeri China dari belenggu sistem feodal Dinasti Qing yang telah berlangsung selama berabadabad tahun. Sistem pemerintahan Dinasti ini dirasa sudah sangat bobrok dan perlu adanya berubahan sistem yang lebih baik..

Sejak berdirinya Republik Rakyat Cina pada tahun 1949, peraturan perundang-undangan yang sistematis telah dibentuk untuk melindungi hakhak dan kepentingan perempuan. Pada era kepemimpinan Mao Zedong, kesetaraan gender sudah mulai dibentuk atau dimasukkan melalui berbagai kebijakan maupun perundang-undangan negara. Dasar ideologi Mao Zhedong berasal dari Marxisme dan komunisme gaya soviet.(Chamberlain \& Meisner, 1987) Mao mengubah ide Soviet untuk memenuhi kebutuhan China 
Jurnal SOSIO DIALEKTIKA 6 (2) (2021)

P-ISSN: 2540.8941 e-ISSN: 2623.2944

e-mail; sosiodialektika@unwahas.ac.id

doi; http://dx.doi.org/10.31942/sd.v6i2.5680
Dinamika Pertumbuhan Feminisme Di China Dalam Perspektif Konstruktivisme

dan membentuk ideologinya sendiri yang disebut Maoisme. Hal tersebut mengubah cara pandang Mao terhadap kaum perempuan. Di eranya ada sebuah slogan yang begitu terkenal yaitu Women hold up half the sky, disana ia ingin menyampaikan pesan bahwa peran perempuan sangat penting bagi kesuksesan China. Penindasan terhadap mereka merupakan hambatan bagi negara, dan perempuan harus berpartisipasi dalam upaya nasional, dimana mereka perlu disambut dalam unit kerja (danwei). Begitu banyak kebijakankebijakan mengenai perempuan yang dibuat pada era ini; kebijakan pelarangan praktek footbindning mengubah undang-undang tentang perkawinan, membuat undang-undang ketenagakerjaan dan sebaginya. Begitu pula pada era ini Mao juga mendirikan organisasi yang menangani isuisu perempuan yaitu All China Women Federtion yang didirikan di China pada 24 Maret 1949. (Fennell, 2009). Organisasi yang dibawahi langsung oleh pemerintah China ini didirikan dengan tujuan awal yaitu sebagai kampanye propaganda untuk meningkatkan literasi di kalangan perempuan. Kini All China Women Federation menjadi lembaga terpenting negara China yang secara khusus menangani kasus perempuan yang dinaungi langsung oleh pemerintah. Organisasi atau Lembaga ini memainkan peran penting dalam memobilisasi perempuan untuk berpartisipasi dalam pembangunan dan untuk mempengaruhi kebijakan tentang hak-hak perempuan dan kesetaraan gender .(Jones \& Presler-Marshall, 2012)

Pasca era Mao Zedong, yaitu era eknomi pasar dibawah pemerintahan Deng Xiao Ping, perempuan China banyak dituntut untuk bekerja lebih karena peralihan system dari ekonomi sosialis menjadi kapitalis. (Naughton, 1993). Banyak perempuan China terkhususnya dari daerah pedesaan berbndong-bondong melakukan urbanisasi karena pemerintah menyediakan lapangan pekerjaan di kota-kota besar guna membangun serta meningkatkan ekonomi negara. Hal tersebut berdampak pada daya saing tinggi diantara para pekerja atau para pemilik modal untuk meraup untung sebesar-besarnya. Dibalik usaha peningkatan ekonomi negara tersebut, sebuah fenomena 
Jurnal SOSIO DIALEKTIKA 6 (2) (2021)

P-ISSN: 2540.8941 e-ISSN: 2623.2944

e-mail; sosiodialektika@unwahas.ac.id

doi; http://dx.doi.org/10.31942/sd.v6i2.5680
Dinamika Pertumbuhan Feminisme Di China Dalam Perspektif Konstruktivisme

Leftover women terjadi. (Weigelin-Schwiedrzik, 2012). Fenomena ketimpangan gender inilah adanya ,perempuan sisa ${ }^{\text {ee }}$ dimana perempuan terlalu sibuk bekerja atau mengejar pendidikan ke tingkat yang lebih tinggi sehingga mereka tidak sadar bahwa umur mereka bertambah dan melupakan bahwa perempuan tersebut juga harus menikah untuk melanjutkan keturunan. Kebanyakan dari kaum laki-laki China tidak mau memilih para perempuan tersebut untuk dinikahi karena; pertama tidak sesuai dengan kriteria mereka, dimana mereka hanya mau menikahi perempuan yang umurnya masih muda. Kedua faktor tingkat pendidikan serta posisi jabatan seorang perempuan dimana jika semakin tinggi maka tingkat kemandirian ikut semakin tinggi pula, dan memunculkan persepsi bahwa perempuan tersebut bisa hidup seorang diri tanpa perlu adanya pendamping.

Di era Deng Xiao Ping pula muncul sebuah kebijakan yang diangap ekstrim di dunia yaitu One Child Policy. Sebuah kebijakan dimana pasangan suami istri yang sudah menikah hanya diperbolehkan untuk memiliki satu anak saja dalam keluarga. Kebijakan ini diperkenalkan pada tahun 1979, kebijkan ini lahir dari adanya ketakutan pemerintahan China terhadap jumlah penduduk yang semakin membludak atau overpopulation. (Shambaugh, 1993). Seperti yang kita ketahui bahwa China menempati posisi pertama dengan populasi penduduk terbesar di dunia. Hal tersebut dianggap oleh pemerintahan dibawah Deng Xiao Ping sebagai ancaman yang akan memberikan dampak buruk pada perekonomian dan kualitas hidup penduduk itu sendiri. Dimana semakin banyak anak maka beban hidup dari segi ekonomi bagi keluarga akan semakin besar pula pengeluarannya. Kebijakan ini bertujuan untuk menekan tingkat kelahiran penduduk. Kebijakan ini dirasa sangat merugikan dari segi kesehatan dan kesetaraan gender antara laki-laki dan perempuan. Hal ini dibuktikan dengan adanya praktek aborsi yang dilegalkan oleh pemerintah, banyak pasangan yang telah memilki anak pertama sengaja melakukan praktek aborsi pada kandungan guna mencegah adanya anak kedua. Selain itu juga banyak tindakan aborsi dengan alasan 
Jurnal SOSIO DIALEKTIKA 6 (2) (2021)

P-ISSN: 2540.8941 e-ISSN: 2623.2944

e-mail; sosiodialektika@unwahas.ac.id

doi; http://dx.doi.org/10.31942/sd.v6i2.5680
Dinamika Pertumbuhan Feminisme Di China Dalam Perspektif Konstruktivisme

perempuan tersebut mengandung anak berjenis kelamin perempuan bukan lakilaki.(Chang, 1996)

Disini kita dapat melihat bahwa akar dari budaya partriarki masih sangat kuat dalam masyarakat sosial China. Anak laki-laki dianggap sebagai topangan kehidupan para orang tua ketika mereka telah menjadi lansia kelak. Selain itu juga anak laki-laki dianggap sebagai penerus keturunan keluarga.

Pada era Ding Xiao Ping juga terjadi momentum yang memberikan dampak begitu besar pada kesetaraan perempuan di China. Tahun 1979 negara ini telah meratifikasi Convention on the Elimination of all Forms of Discrimination Against Women (CEDAW). (Englehart \& Miller, 2014). Meratifikasi CEDAW sama artinya dengan menerima norma-norma internasional tentang kesetaraan gender yang pada gilirannya akan meminta undangundang domestik untuk membuat beberapa perubahan yang sesuai dengan isu tersebut. Sesuai dengan ketentuan dari CEDAW, China telah mengambil banyak tindakan yang sesuai dalam aspek legislatif. Serangkaian undang-undang dan peraturan yang mempromosikan kesetaraan gender seperti UU Perkawinan, dan Undang-Undang Anti Kekerasan Dalam Rumah Tangga.(SS., 2015)

Selain merativikasi CEDAW, pada tahun 1995 China lebih tepatnya di Beijing diselenggarakan Fourth World Conference on Women in Beijing, sebuah konferensi yang berfokus pada tindakan untuk kesetaraan, pembangunan, dan perdamaian. Pemerintah China menyesponsori konferensi tersebut dan kemudian menandatangani dokumen United Nation yang menjanjikan kesetaraan gender, dan organisasi wanita resmi, aktivis feminis dan ilmuwan yang telah berjuang melawan diskriminasi gender dan bekerja untuk mencapai kesetaraan gender.(Cho, 2014)Salah satu hasil yang sangat penting dari Konferensi Beijing ini adalah kenyataan bahwa kekerasan terhadap perempuan sebagai masalah hak asasi manusia adalah suatu hal yang begitu nyata. 
Jurnal SOSIO DIALEKTIKA 6 (2) (2021)

P-ISSN: 2540.8941 e-ISSN: 2623.2944

e-mail; sosiodialektika@unwahas.ac.id

doi; http://dx.doi.org/10.31942/sd.v6i2.5680
Dinamika Pertumbuhan Feminisme Di China Dalam Perspektif Konstruktivisme

Dari dua momentum yaitu terativikasinya CEDAW pada tahun 1979 dan diselenggarakannya Beijing Platform for Action tahun 1995 dimana China menjadi tuan rumah dari konvensi tersebut menjadikan dua momentum tersebut sebagai landasan dasar pengambilan kebijakan tentang kesetraan gender di China.(The United Nations, 1995). Pada tahun 2015, China mulai memberlakukan undang-undang nasional pertamanya yang melarang kekerasan dalam rumah tangga, meskipun itu tidak termasuk untuk pasangan sesama jenis dan tidak menangani kekerasan seksual. Undang-undang tersebut juga mendefinisikan kekerasan dalam rumah tangga untuk pertama kalinya. (Moser \& Moser, 2005) Dimana kasus kekerasan dalam rumah tangga telah menjadi subyek banyak perdebatan publik di China sejak tahun 2011,(Platform \& Island, 2009) ketika kasus Kim Lee yang menjadi korban kekerasan oleh suaminya terangkat di media massa. Walaupun kebijakan berbasis kesetaraan gender sudah dibuat dan diberlakukan, namun masih banyak contoh kasus diskriminasi pada isu tersebut. Seperti selain pengesahan undang-undang tersebut ditahun yang sama pada bulan maret tepatnya ketika malam dihari International Women Day, lima feminis muda China ditangkap karena telah membuat masalah. Lima femnis tersebut adalah Li Tingting, Wei Tingting, ZhengChuran, Wu Rongrong, dan Wang Man . Mereka dikenal sebagai "Feminis Five," yang telah lama menjadi pendukung undang-undang mengenai kekerasan dalam rumah tangga di China. (Wang \& Driscoll, 2019). Lima Feminist ini ditangkap karena merencanakan kampanye protes terhadap pelecehan seksual di transportasi umum. Kelompok ini juga terlibat dalam demonstrasi menentang ketidaksetaraan gender di China dan melakukan seni pertunjukan mengenai hak LGBT di China. Mereka menggunakan seni dalam melakukan aksi protes dan merupakan bagian penting dari aktivisme mereka karena demonstrasi publik dilarang di China.(Wu \& Dong, 2019)

Fenomena proses pertumbuhan feminisme di China menarik untuk dikaji, karena fenomena feminisme dan kesetaraan gender di China lebih 
Jurnal SOSIO DIALEKTIKA 6 (2) (2021)

P-ISSN: 2540.8941 e-ISSN: 2623.2944

e-mail; sosiodialektika@unwahas.ac.id

doi; http://dx.doi.org/10.31942/sd.v6i2.5680
Dinamika Pertumbuhan Feminisme Di China Dalam Perspektif Konstruktivisme

kompleks daripada apa yang sering digambarkan atau negara lain alami. Pada awal mulanya budaya sistem patriarki di China begitu kuat dalam sistem sosial masyarakat, sehingga peranan perempuan memiliki porsi yang sangat sedikit dibandingkan dengan laki-laki. Perempuan begitu tersubordinasi dibawah laki-laki, namun seiring berkembangnya era, ide-ide baru dan muncul kaum-kaum intelektual yang sadar akan isu perempuan dapat menggeser pemikiran-pemikiran tradisional atas peranan perempuan dalam keluarga dan masyarakat melalui gagasan femnisme itu sendiri.

\section{B. METODE}

Metode yang dipakai dalam penelitian ini adalah metode penelitian kualitatif, dengan menggunakan metode kepustakaan dan studi pustaka/riset Pustaka. Studi pustaka adalah istilah lain dari kajian pustaka, tinjauan pustaka, kajian teoritis, landasan teori, telaah pustaka (literature review), dan tinjauan teoritis. Yang dimaksud penelitian kepustakaan adalah penelitian yang dilakukan hanya berdasarkan atas karya tertulis, termasuk hasil penelitian baik yang telah maupun yang belum dipublikasikan (Bowen, 2009). Meskipun merupakan sebuah penelitian, penelitian dengan studi literatur tidak harus turun ke lapangan dan bertemu dengan responden. Datadata yang dibutuhkan dalam penelitian dapat diperoleh dari sumber pustaka atau dokumen. Riset pustaka (library research), penelusuran pustaka tidak hanya untuk langkah awal menyiapkan kerangka penelitian (research design) akan tetapi sekaligus memanfaatkan sumber-sumber perpustakaan untuk memperoleh data penelitian. Selain data, (Silverman, 2004) (Silverman, 2004) beberapa hal yang harus ada dalam sebuah penelitian supaya dapat dikatakan ilmiah, juga memerlukan hal lain seperti rumusan masalah, landasan teori, analisis data, dan pengambilan kesimpulan. penelitian dengan studi literatur adalah penelitian yang persiapannya sama dengan penelitian lainnya akan tetapi sumber dan metode pengumpulan data dengan mengambil data di pustaka, membaca, mencatat, dan mengolah bahan penelitian. 
Jurnal SOSIO DIALEKTIKA 6 (2) (2021)

P-ISSN: 2540.8941 e-ISSN: 2623.2944

e-mail; sosiodialektika@unwahas.ac.id

doi; http://dx.doi.org/10.31942/sd.v6i2.5680
Dinamika Pertumbuhan Feminisme Di China Dalam Perspektif Konstruktivisme

Pengumpulan data diambil dengan pendekatan kualitatif, yaitu peneliti sebagai instrument utama untuk pengumpulan data dan pengolahan atau analisis data, serta sangat memfokuskan perhatian pada proses dan arti dari suatu peristiwa yang diteliti. Dalam pendekatan kualitatif, penelitian dapat dilakukan dalam tiga tahapan utama, yaitu (1) Pengumpulan Data (Data Collective); (2) Pengolahan Data (Data Analysis); dan (3) Laporan Penelitian (Report Writing).(Creswell, 2007)

\section{PEMBAHASAN}

\section{C.1. Tahap Kemunculan Feminisme}

Budaya partiarki yang sudah mendarah daging dalam masyarakat China sendiri telah mengakibatkan banyak sekali ketidakseimbangan hubungan antara laki-laki dan perempuan dalam kehidupan sosial masyarakat. Sistem sosial patriarki menjadikan laki-laki memiliki hak istimewa terhadap perempuan. Perempuan begitu tersubordinasi dibawah laki-laki. (Howell, 2002). Dominasi laki-laki terhadap perempuan tidak hanya mencakup ranah personal saja, melainkan juga dalam ranah yang lebih luas seperti partisipasi politik, pendidikan, ekonomi, sosial, hukum dan lain-lain. Hal ini menyebabkan ketidakheranan bahwa perempuan pada era tersebut begitu bergantung pada kaum laki-laki, dan dianggap bahwa mereka adalah makhluk yang lemah dan harus dilindungi.

Dalam kehidupan masyarakat China, terutama sebelum RRC berdiri, pranata sosial yang paling penting adalah keluarga. Memahami keluarga membantu memahami kehidupan orang China dan sikap kaum pria dan wanita yang membentuk keluarga tersebut .(Haiping, 2006) Dahulu, keluargalah yang merupakan unit sosial yang paling kecil dan bukan individu. Keluarga atau chia dalam masyarakat Cina tradisional adalah kelompok kekerabatan yang diatur menurut sistem patrilineal. Istilah ini berarti bahwa keturunan dihitung menurut garis laki-laki. Hal 
Jurnal SOSIO DIALEKTIKA 6 (2) (2021)

P-ISSN: 2540.8941 e-ISSN: 2623.2944

e-mail; sosiodialektika@unwahas.ac.id

doi; http://dx.doi.org/10.31942/sd.v6i2.5680
Dinamika Pertumbuhan Feminisme Di China Dalam Perspektif Konstruktivisme

tersebut termasuk pembagian harta warisan dan pemujaan leluhur. Bagi masyarakat Cina, keluarga tidak hanya terdiri atas orang-orang yang masih hidup, tetapi juga leluhur yang telah meninggal dan keturunan yang nantinya akan dilahirkan. Seperti yang diungkapkan oleh Hugh Baker: "he exists by virtue of his ancestors, and his descendants exist only trough him... The individual exists by virtue of his descendants, and that his ancestors exist only trough him “ (Hu et al., 2010). Keberadaan dan kelestarian leluhur serta posisi mereka dalam keluarga akan tetap sebagaimana seharusnya, jika anggota keluarga yang masih hidup tetap melakukan berbagai aktivitas yang menunjukkan keberadaan mereka melalui ritual pemujaan leluhur. Tradisi ritual tersebut dilakukan dengan tujuan meminta berkah pada leluhur dan dijauhkan dari kesialan. Dengan doa dan berkah yang diberikan leluhur, maka keberadaan dan kelangsungan suatu individu dan juga keturunannya juga ditentukan oleh leluhur. Jadi, hubungan yang diungkapkan dalam pernyataan diatas tidak hanya sekedar hubungan fisik atau biologis yang kasat mata saja, tetapi lebih pada hubungan kelangsungan garis keturunan. Arthur Wolf menyebut hubungan ini sebagai descent line (Morishima, 1982)

Pentingnya keluarga bagi masyarakat Cina tergambar dengan jelas pada konsep wu lun (lima hubungan) yang diajarkan oleh Konfusius untuk menjaga keharmonisan dalam keluarga. Lima hubungan itu adalah: hubungan antara raja dan bawahan, ayah dan anak laki-laki, kakak laki-laki dan adik laki-laki, suami dan istri, dan antar teman. Tiga dari lima hubungan yang dikonsepkan oleh Konfusius di atas membicarakan masalah keluarga. Hal itu menunjukkan keluarga merupakan institusi yang penting untuk dijaga keharmonisannya.(Lasiyo, 2018) Rendahnya posisi wanita di mata masyarakat Cina tradisional yang merupakan penganut Konfusianisme tergambar dengan jelas pada kitab-kitab Konfusius, termasuk dalam 
Jurnal SOSIO DIALEKTIKA 6 (2) (2021)

P-ISSN: 2540.8941 e-ISSN: 2623.2944

e-mail; sosiodialektika@unwahas.ac.id

doi; http://dx.doi.org/10.31942/sd.v6i2.5680
Dinamika Pertumbuhan Feminisme Di China Dalam Perspektif Konstruktivisme

konsep wu lun di atas yang hanya menyebut perempuan satu kali saja. Itu pun jika mereka telah menikah dan melahirkan anak laki-laki. Peran dan posisi mereka di mata masyarakat tidak signifikan seperti halnya laki-laki. Salah satu kitab ajaran Konfusius, kitab puisi atau Shijing, dengan jelas menggambarkan dan menjadi dasar praktik zhong nan qing nü atau praktik meninggikan lelaki dan merendahkan perempuan, yang berlaku dalam masyarakat tradisional China. Berikut adalah potongan puisi yang terdapat pada Shijing (Legged,306-307).

Ketika seorang bayi laki-laki lahir

Dia dibaringkan di peraduan,

Diberi busana panjang yang pantas,

Dan diberi batu giok sebagai mainan,

Tangis dan jeritnya kuat menggema,

Kelak ia akan memegang kekuasaan

Raja dalam rumah tangganya

Ketika seorang bayi perempuan lahir

Dia dibaringkan di atas tanah,

Diberi kain sebagai pakaian

Diberi pecahan genting sebagai mainan,

Darinya tidak ada yang diharapkan,

Kelak ia hanya memikirkan roh leluhur dan makanan

Sekedar tidak membuat susah orang tua

Dari puisi di atas tergambar dengan jelas bahwa wanita China memiliki posisi yang lebih rendah, bahkan tidak berharga sama sekali. Peran dan posisi laki-laki dan perempuan sudah dibedakan sejak bayi. Rendahnya posisi perempuan ini bahkan hingga kematian. Nasib roh perempuan tergantung pada pemujaan yang dilakukan oleh keturunannya melalui garis laki-laki.

Di antara berbagai peraturan yang harus dipatuhi oleh perempuan Cina adalah aturan Tiga Kepatuhan, yaitu patuh pada orang tua selama ia belum menikah, pada suami setelah ia menikah, dan pada anak laki- 
Jurnal SOSIO DIALEKTIKA 6 (2) (2021)

P-ISSN: 2540.8941 e-ISSN: 2623.2944

e-mail; sosiodialektika@unwahas.ac.id

doi; http://dx.doi.org/10.31942/sd.v6i2.5680
Dinamika Pertumbuhan Feminisme Di China Dalam Perspektif Konstruktivisme

laki setelah suaminya meninggal dunia. Aturan tersebut kemudian menjadi dasar bahwa seorang wanita menjadi milik suami dan keluarga suaminya setelah ia menikah. Sebab, seorang perempuan secara eksplisit pindah dari rumah atau keluarga kandungnya, tempat dia lahir (niangjia) dan menjadi anggota keluarga suaminya (pojia). (Selden \& Perry, 2010)Dalam kehidupan berumah tangga, posisinya sebagai seorang istri dalam keluarga suaminya secara teoritis sangat tidak aman. Ketika menikah, maka ia berada di bawah kekuasaan keluarga suaminya, termasuk ibu mertuanya. Secara hukum, dia dapat diceraikan atau dikeluarkan dari keluarga jika terdapat salah satu dari tujuh alasan berikut: mandul, berprilaku kejam, mengacuhkan mertua, cerewet, mencuri, pencemburu dan dengki, mengidap penyakit berbahaya. (Baker, 1979: 45)

Kemandulan atau tidak memiliki anak laki-laki merupakan salah satu hal yang paling menakutkan. Seperti halnya mengabaikan mertua, kemandulan juga membahayakan kelangsungan keluarga dan keberadaan seorang perempuan dalam keluarga suaminya. Karena dengan tidak adanya keturunan yang diperoleh dari seorang istri maka pemujaan leluhur tidak dapat dilaksanakan. Hal itu berarti kelangsungan dan kelestarian silsilah keluarga terancam dan rohnya tidak ada yang merawat.

Budaya patriarki dan nilai-nilai Konfusianisme yang dipegang oleh masyarakat China tradisional menyebabkan kaum wanita mendapat status dan posisi yang lebih rendah daripada laki-laki. (Yifei, 2011). Bahkan, dapat dikatakan bahwa mereka tidak mempunyai hak sama sekali dalam hidupnya. Hal itu terlihat misalnya dalam hal perkawinan dan tradisi pemujaan leluhur. Perkawinan adalah peristiwa yang hanya boleh dilakukan oleh seorang wanita sekali seumur hidupnya. Itu pun merupakan sesuatu yang berada di luar kekuasaan wanita. Jika ada wanita yang menikah lebih dari satu kali, maka wanita itu dianggap telah melanggap pantangan dan melakukan kejahatan besar. Oleh karena itu, harus dihukum dan mendapat sanksi.(Gao, 2015) 
Jurnal SOSIO DIALEKTIKA 6 (2) (2021)

P-ISSN: 2540.8941 e-ISSN: 2623.2944

e-mail; sosiodialektika@unwahas.ac.id

doi; http://dx.doi.org/10.31942/sd.v6i2.5680
Dinamika Pertumbuhan Feminisme Di China Dalam Perspektif Konstruktivisme

Setelah adanya Perang Candu (Opium war) terjadi pada abad ke10, (Marlow, 2018) China mulai mengalami krisis militer dan politik baik dari dalam maupun luar negeri. Perang ini telah memaksa China membuka pintu perdagangan dengan negara lain sebagai hasil penandatanganan perjanjian Nanjing dengan Inggris. Hal ini merupakan awal mula masuknya ideologi baru paham baru seperti feminisme yang dibawa oleh bangsa barat ke daratan China.(Knechtges et al., 1977)

Oleh karena kemunculan paham-paham baru yang didatangkan oleh bangsa barat, hal tersebut banyak mengisnpirasi para intelektual lokal China untuk berpikir bahwa harus adanya perubahan sistem yang selama ini hanya diamalkan oleh masyarakat tanpa bertanya-tanya bahwasanya sistem tersebut memiliki banyak kekurangan dan banyak merugikan masyarakat itu sendiri. Sebagai contoh kasus adalah praktek footbinding terhadap perempuan, (Berry \& Sang, 2004) dimana praktek ini begitu menyiksa dan memiliki dampak yang sangat serius bagi kesehatan perempuan itu sendiri.

Muncul salah satu tokoh perempuan yang terkenal yaitu, He Zhen dengan yang merupakan karakter penting dalam pembahasan feminisme China, ia dipandang sebagai katalisator pergerakan perempuan. He Zhen berperan sebagai agen perubahan (norm entrepreneurs) yang memiliki gagasan mengenai perempuan di China. Ia berusaha untuk mengadopsi paham feminisme barat dengan tidak meninggalkan identitas budaya China yang dirasa baik bagi perubahan sosial kaum perempuan. Berbeda dengan tokoh pembaharu lainnya, dimana He Zhen secara khusus memisahkan kasus feminisme dari nasionalisme, dengan menyatakan bahwa pembebasan perempuan bukanlah demi bangsa, melainkan semua itu adalah sebuah kebutuhan moral. Disini sangat terlihat jelas bahwa He Zhen sebagai norm enterpreneurs sangat memerhatikan alutruisme dan rasa empati terhadap nasib perempuan di China.(Roces, 2010)

He Zhen mangkaji bahwasannya perempuan China masih dalam kungkungan sistem partriarki yang membatasi gerak perempuan itu 
Jurnal SOSIO DIALEKTIKA 6 (2) (2021)

P-ISSN: 2540.8941 e-ISSN: 2623.2944

e-mail; sosiodialektika@unwahas.ac.id

doi; http://dx.doi.org/10.31942/sd.v6i2.5680
Dinamika Pertumbuhan Feminisme Di China Dalam Perspektif Konstruktivisme

sendiri.(Haiping, 2006) Ia menoba menjawab mengapa hingga pada masa itu isu terhadap perempuan tetap berlangsung, hal tersebut dikarenakan selama ribuan tahun, dunia telah didominasi oleh aturan manusia. Dimana aturan ini ditandai oleh pembedaan kelas, hanya lakilaki saja yang menggunakan hak kepemilikan pribadi. Menurutnya untuk memperbaiki masalah tersebut, langkah pertama menurut yaitu harus dihapuskannya aturan yang menitikberatkan kepada kaum lakilaki dan memperkenalkan kesetraan antara sesama manusia, yang berarti bahwa dunia harus sama-sama dimiliki oleh laki-laki maupun perempuan. Tujuan kesetaraan tersebut tidak akan tercapai kecuali melalui pembebasan perempuan .(W. Zheng, 2016). He Zhen juga berkerjasama dengan gerakan Nasionalis, dengan tujuan menyuarakan kesetaraan, walaupun pada waktu itu isu-isu kesetaraan perempuan masih dipandang sebagai isu sekunder yang merupakan bagian demi tercapainya nasionalisme untuk menggulingkan sistem feodal Dinasti Qing.

Setelah adanya pembaharuan sistem, dimana bangsa China kini telah berubah sebagai sebuah negara, isu-isu perempuan juga mulai dilirik sebagai salah satu cara untuk memajukan negara itu sendiri. Terlihat jelas pada era kepemimpinan Mao Zedong yang memiliki slogan khusus terhadap perempuan yaitu Women hold up half the sky.(W. Zheng, 1997) Mao Zedong menyampaikan pesan bahwasanya peran perempuan sangat penting bagi kesuksesan dan kemajuan neara China. Penindasan terhadap mereka merupakan hambatan bagi negara. (Knechtges et al., 1977)Mao sendiri banyak melakukan perubahanperubahan dasar yang berdampak pada adanya kesetaraan gender. Seperti Mao meratifikasi konstitusi pertamanya pada tahun 1954 dan menyatakan bahwa status perempuan sebagai warga negara adalah penuh. Pasal 91 Konstitusi memberi perempuan hak yang setara dengan laki-laki di semua bidang kehidupan politik, ekonomi, budaya, sosial, dan domestik. Undang- undang dan peraturan baru mengizinkan seorang perempuan untuk memperbolehkan perceraian, memiliki properti, mengenyam pendidikan formal dan menerima upah yang sama 
untuk pekerjaan yang sama. (Knechtges et al., 1977). Selain memberikan langkah-langkah kesetaraan semacam itu, Partai Komunis China juga menganggap perempuan berkontribusi bagi angkatan kerja untuk menjadi bagian integral dari pembangunan negara. Selain itu ada pula kebijakan penghentian praktek footbinding pada tahun 1949. Menurutnya perempuan akan terbatas geraknya, dan hal tersebut menyebabkan macetnya pekerjaan yang berdampak pada ekonomi pada masa itu karena perempuan dianggap sebagai suksesor ekonomi sosialis.

Selama periode Revolusi Kebudayaan (1966-1976), partisipasi perempuan dalam angkatan kerja meningkat, dengan beberapa perempuan bahkan mengambil posisi kepemimpinan dan pekerjaan yang secara tradisional dipegang oleh laki-laki. Disini dapat kita lihat bahwa kesadaran akan isu-isu feminisme telah diadopsi sebagai norma dan sebagai alat propaganda pemerintah guna memajukan negara.(Tryggestad, 2014) Hal ini merupakan fase tipping point bagaimana China telah menyadari dibutuhkannya norma dalam hal ini feminisme sebgai penunjang pengingkatan guna kemajuan negara.

\section{C.2. Pengaruh Organisasi Internasional Terhadap Kebijakan Kesetaraan}

Dalam kasus proses pertumbuhan feminisme di China sendiri dapat dilihat adanya pengaruh rativikasi negara China terhadap Convention Elimination of All Forms of Discrimination against Women (CEDAW) Pada 17 Juli 1980 pada Second World Conference on Women yang diselenggarakan di Copenhagen Denmark. Dimana pada bulan September 1980, (SS., 2015) Dewan Negara China mempresentasikan "the Bill of Requesting for Ratification of the Convention on the Elimination of All Forms of Discrimination against Women of the United Nations" kepada Komite Tetap Kongres Rakyat Nasional.(Gardam, 1998)

Dengan meratifikasi konvensi tersebut berarti China telah berkomitmen untuk melakukan serangkaian tindakan untuk mengakhiri 
Jurnal SOSIO DIALEKTIKA 6 (2) (2021)

P-ISSN: 2540.8941 e-ISSN: 2623.2944

e-mail; sosiodialektika@unwahas.ac.id

doi; http://dx.doi.org/10.31942/sd.v6i2.5680
Dinamika Pertumbuhan Feminisme Di China Dalam Perspektif Konstruktivisme

diskriminasi terhadap perempuan dalam segala bentuk. Meratifikasi CEDAW sama artinya dengan menerima norma-norma internasional tentang kesetaraan gender yang pada gilirannya akan meminta undangundang domestik untuk membuat beberapa perubahan yang sesuai dengan isu tersebut. Sesuai dengan ketentuan dari CEDAW,(Gardam, 1998) China telah mengambil banyak tindakan yang sesuai dalam aspek legislatif. Serangkaian undang-undang dan peraturan yang mempromosikan kesetaraan gender termasuk;(Shalev, 2001) UU Perkawinan, Prinsip Umum Hukum Perdata, Undang-Undang Anti Kekerasan Dalam Rumah Tangga, Hukum Kontrak Tenaga Kerja, Undang-Undang Pendidikan Wajib, Hukum Waris, Undang-Undang Promosi Ketenagakerjaan, Undang- Undang Asuransi Sosial, dan Undang-Undang tentang Maternal dan Perawatan Kesehatan Anak telah diberlakukan berdasarkan Hukum Konstitusi dengan Undangundang Republik Rakyat China tentang Perlindungan Hak dan Kepentingan Perempuan (Liu B. , Human Rights, No. 1 (2010), at 6) dan telah membuat dasar yang kuat untuk pencapaian hak-hak perempuan yang sah.

Contoh kasus lain bagaimana konvensi CEDAW ini mampu mempengaruhi peraturan perundang-undangan maupun kebijakan dapat kita lihat pada pemulihan hukum dilakukan sejak Sidang Pleno ke-3 tentang undang-undang perkawinan yang disahkan pada Kongres Rakyat Nasional tahun 1980 dan direvisi pada tahun 2001, dimana ditambahkan tentang larangan perselingkuhan bagi mereka pasangan yang telah menikah dengan pihak ketiga mana pun, larangan kekerasan dalam rumah tangga, kesetiaan antara suami dan istri, membatalkan sistem perkawinan, prinsip kompensasi perceraian, prinsip kompensasi kesalahan dan masalah properti yang dimurnikan dan sebagainya. Ketentuan-ketentuan baru tersebut dapat berfungsi sebagai jaminan hak 
Jurnal SOSIO DIALEKTIKA 6 (2) (2021)

P-ISSN: 2540.8941 e-ISSN: 2623.2944

e-mail; sosiodialektika@unwahas.ac.id

doi; http://dx.doi.org/10.31942/sd.v6i2.5680
Dinamika Pertumbuhan Feminisme Di China Dalam Perspektif Konstruktivisme

dan kepentingan bagi pihak yang tidak diuntungkan dalam hubungan perkawinan, terutama perempuan (Englehart \& Miller, 2014)

Selain adanya CEDAW momentum lain yang mempengaruhi perubahan feminisme China adalah Beijing Declaration (Deklarasi Beijing) dan Beijing Platform for Action (BPFA) tahun 1995 yang diadakan di Beijing, China.(Beijing Platform for Action, 1995) Platform for Action merupakan sebuah agenda pemberdayaan perempuan. Hal ini bertujuan mempercepat implementasi hasil dari Third World Conference on Women di Nairobi tahun 1985 (O’Brien \& Gemelli, 2012) yang bertujuan untuk kemajuan perempuan dan menghilangkan semua hambatan untuk partisipasi aktif perempuan di semua bidang kehidupan baik itu publik maupun pribadi melalui kesetaraan dalam bidang ekonomi, sosial, budaya dan politik. Pengambilan keputusan ini berarti bahwa prinsip kekuasaan dan tanggung jawab bersama harus ditetapkan antara perempuan dan lakilaki di baik itu rumah, di tempat kerja dan di komunitas nasional dan internasional yang lebih luas. Kesetaraan antara perempuan dan lakilaki adalah masalah hak asasi manusia dan syarat untuk keadilan sosial dan juga merupakan prasyarat mendasar dan penting bagi kesetaraan, pembangunan dan perdamaian. (United Nations, 1995) Kemitraan yang berubah berdasarkan kesetaraan antara perempuan dan laki- laki adalah kondisi untuk pembangunan berkelanjutan yang berpusat pada masyarakat. Deklarasi menyerukan kepada negara-negara anggota untuk berkomitmen pada kemajuan tujuan kesetaraan, pembangunan dan perdamaian bagi semua perempuan dan menegaskan kembali prinsip dasar bahwa hak-hak perempuan dan anak perempuan adalah bagian yang tidak dapat dicabut, dan tidak terpisahkan dari hak asasi manusia universal.

Menjadi tuan rumah Konferensi Dunia ke-4 China di Beijing pada tahun 1995 merupakan titik balik utama dalam menangani isu 
Jurnal SOSIO DIALEKTIKA 6 (2) (2021)

P-ISSN: 2540.8941 e-ISSN: 2623.2944

e-mail; sosiodialektika@unwahas.ac.id

doi; http://dx.doi.org/10.31942/sd.v6i2.5680
Dinamika Pertumbuhan Feminisme Di China Dalam Perspektif Konstruktivisme

perempuan di negara ini. Acara ini telah berfungsi sebagai katalis dalam meningkatkan keterlibatan perempuan dalam politik, yang menghasilkan berbagai peraturan mengenai gender. CEDAW dan Beijing Platform fo Action pada thun 1995 telah menjadi landasan hukum dalam membuat atau mengambil kebijakan serta perundangundangan tentang isu perempuan di China.(Moser \& Moser, 2005)

\section{C.3. Pelembagaan Isu Feminisme di China}

Dalam kasus yang penulis bahas, dapat menarik jawaban bahwa China sendiri telah mencoba dalam tahap menyelaraskan perilaku norma yang membawa isu tentang perempuan kedalam tatanan sosial serta kebudayaan yang dimilikinya,(Haiping, 2006) atau dengan kata lain proses pertumbuhan femnisme China sendiri tidak akan pernah terlepas dengan adanya proses peleburan dengan budaya didalam tubuh feminisme itu sendiri, atau dengan kata lain feminisme yang berkembang memiliki ciri unik tersendiri yang tidak dimilki oleh negara lainnya dan hanya negara China yang memilikinya.

Hal ini dapat dilihat dari banyaknya persentase keterlibatan perempuan dalam politik parlemen China. Rasio keterwakilan perempuan di Kongres Rakyat Nasional ke-12, badan legislatif tertinggi, mencapai rekor tertinggi yaitu perempuan menyumbang 23,4\%, 2,1 poin persentase lebih tinggi daripada kongres sebelumnya yang diadakan lima tahun lalu. Perempuan juga menyumbang 39,9 persen dari anggota dewan direksi pada tahun 2016, jumlah ini meningkat dibandingkan dengan 32,7\% pada tahun 2010. Perempuan menduduki 699 kursi parlemen dengan persentase 23,4\% dari total anggotan parlemen. China juga menduduki peringkat ke 62 dunia penyumbang jumlah perempuan terbanyak pada parlemen pada tahun 2017 (BBC, 2020).

Kenaikan keterwakilan perempuan dalam Central Committee of China atau yang sering dikenal sebagai Komite Sentral Partai Komunis 
China juga meningkat. Dimana Komite ini adalah sebuah badan politik yang beranggotakan para pemimpin tertinggi Partai Komunis China atau PKC(Brown, 2012). Komite Sentral China telah berdiri sejak tahun 1927 dan perkembangannya dimulai sangat pesat pada tahun 1978, pada saat refomasi ekonomi terjadi di China. Dalam praktiknya Komite Sentral 'bekerja' ketika kongres nasional sedang tidak berjalan. Kongres nasional terjadi setiap lima tahun sekali, sedangkan pleno Komite terjadi setidaknya setiap satu tahun sekali. Pleno Komite berfungsi sebagai tempat dimana beberapa kebijakan dirancang, dibahas, disesuaikan, hingga akhirnya dipublikasikan dan diterapkan kepada publik. Selain itu, Komite Sentral juga berfungsi dan memiliki kekuatan penuh untuk memilih Sekjen atau Sekretaris Jenderal Politburo,Komisi tetap, dan Komisi Militer Pusat. Dalam penjelasan kali ini akan dibahas lebih lanjut mengenai Komite Sentral ke tujuh belas.

Komite Sentral ke-17 dinilai sebagai Komite yang cukup kuat. Hal ini dikarenakan anggota dari Komite Sentral ke-17 ini beranggotakan 204 anggota penuh (full members) dan 167 anggota alternatif atau (alternative members), jika ditotal maka anggota komite Sentral ke-17 beranggotakan sebanyak 371 orang. (Pieke, 2012)Dalam penjelasan Komite Sentral ke-17 ini akan dijelaskan mengenai tingkat Pendidikan, usia, pengalaman kerja, kedudukan partai, provinsi asal, gender, dan juga kebangsaan. 
Jurnal SOSIO DIALEKTIKA 6 (2) (2021)

P-ISSN: 2540.8941 e-ISSN: 2623.2944

e-mail; sosiodialektika@unwahas.ac.id doi; http://dx.doi.org/10.31942/sd.v6i2.5680
Dinamika Pertumbuhan Feminisme Di China Dalam Perspektif Konstruktivisme

Dibandingkan dengan Komite ke-16 Komite ke-17 memiliki lebih banyak perwakilan perempuan didalamnya.

Tabel. 1. Anggota Perempuan dalam Komite Central

\begin{tabular}{lcc}
\hline & FREKUENSI & PERSENTASE \\
\hline KOMITE CENTRAL KE 17 & & \\
\hline FULL MEMBERS & 13 & 35.13 .00 \\
\hline ALTERNATIVE MEMBERS & 24 & 64.86 \\
\hline TOTAL & 37 & 100.00 .00 \\
\hline
\end{tabular}

KOMITE CENTRAL KE 16

\begin{tabular}{lcc}
\hline FULL MEMBERS & 5 & 18.52 \\
\hline ALTERNATIF MEMBERS & 22 & 81.48 .00 \\
\hline TOTAL & 27 & 100.00 .00 \\
\hline
\end{tabular}

KOMITE SENTRAL KE 15

\begin{tabular}{lcc}
\hline FULL MEMBERS & 8 & 32.00 .00 \\
\hline ALTERNATIVE MEMBERS & 17 & 68.00 .00 \\
\hline TOTAL & 25 & 100.00 .00 \\
\hline
\end{tabular}

Sumber: "Document 9: A ChinaFile Translation". www.chinafile.com/document-9-chinafile-translation. Diakses pada tanggal 06 Nopember 2020, pukul 15.00 wib

Dari table tentang anggota komite ada jumlah yang cukup tinggi dalam hal anggota komite perempuan. Kalau tingkat dunia, untuk proporsi perempuan dalam parlemen China sudah diatas Indonesia, India, Sierra Leone, Suriah, Nigeria, Thailand, Iran, Libanon dan Papua Nugini. 
Tabel.2. Proporsi Perempuan dalam Parlemen di berbagai negara

\begin{tabular}{lc}
\hline NEGARA & PROSENTASE (\%) \\
\hline Rwanda & 64 \\
\hline Bolivia & 53 \\
\hline Kuba & 49 \\
\hline Swedia, Seychelles & 44 \\
\hline Inggris & 29 \\
\hline China, Estonia, Vietnam & 24 \\
\hline Tajikistan, Amerika Serikat & 19 \\
\hline Indonesia & 17,32 \\
\hline India, Sierra Leone, Suriah & 12 \\
\hline Nigeria, Thailand, dan Iran & 6 \\
\hline Libanon dan Papua Nugini & 3 \\
\hline
\end{tabular}

Sumber:

https://www.bbc.com/indonesia/dunia/2016/05/160502_dunia_iran_pere mpuan_parlemen, diakses, tanggal 6 Nopember 2020, pukul 17.00 wib

Dalam bidang pendidikan pada tahun 2012, rata-rata lama pendidikan perempuan di China telah meningkat menjadi 8,6 tahun. Kesenjangan gender antara laki-laki dan pendidikan perempuan ratarata adalah 0,7 tahun. Ditahun tahun yang sama mahasiswa perempuan di pendidikan tinggi menyumbang $51,4 \%$ dari total pendaftaran universitas. pada tahun 2016, 50,6\% mahasiswa pascasarjana adalah perempuan, melebihi persentase laki-laki untuk pertama kalinya. Ditahun yang sama perempuan juga menyumbang 52,5\% dari keseluruhan total mahasiswa yang menempuh jenjang pendidikan tinggi.(OECD, 2016)

Pada tahun 2013, tingkat pendaftaran bersih anak perempuan di sekolah dasar mencapai 99,72\%. Data menunjukkan 99,6821 juta perempuan pedesaan China berpartisipasi dalam pelatihan keterampilan praktis, dan mereka menyumbang $46,6 \%$ dari total peserta antara dari 
tahun 2006-2010 (China MOE, 2010). Dalam lima tahun terakhir, Federasi Perempuan di berbagai tingkatan telah melatih sekitar lima juta perempuan pedesaan dan membudayakan satu juta perempuan yang terlibat dalam kegiatan wirausaha. Sekitar $43,1 \%$ tenaga kerja negara adalah perempuan pada akhir tahun 2016, dengan jumlah pekerja perempuan di daerah perkotaan mencapai 65,18 juta, jumlah ini naik 34\% dari 2010.

Selain itu, perempuan China kini mulai tersadar pada hak- haknya sebagai seorang perempuan yang memiliki hak yang sama dengan lakilaki. Dimana perempuan China mulai berani untuk membuka suara terhadap diskriminasi yang mereka peroleh dari sistem sosial. Seperti contoh kasus aksi protes Feminist Five tahun 2015 terhadap pelecehan perempuan yang terjadi pada pelayanan transportasi umum milik publik. Aksi protes tersebut berakhir dengan drama penangkapan para aktivis karena dianggap menyalahi aturan demonstrasi.

Walaupun gender-gap masih terus ada di China namun kesadaran akan kesetaraan perempuan diberbagi bidang penting seperti partisipasi politik, pendidikan serta pekerjaan pemerintah dan masyarakat China pun sudah sadar akan hal tersebut. Laju pertumbuhan feminisme di China terbilang sudah optimal, walaupun terkadang dalam prakteknya masih saja ada diskriminasi perempuan dalam berbagai aspek yang kita tidak bisa hindarkan begitu saja.

\section{SIMPULAN}

Fenomena proses pertumbuhan feminisme di China menarik untuk dikaji, karena fenomena feminisme dan kesetaraan gender di China lebih kompleks daripada apa yang sering digambarkan atau negara lain alami. Pada awal mulanya budaya sistem patriarki di China begitu kuat dalam sistem sosial masyarakat, sehingga peranan perempuan memiliki porsi yang sangat sedikit dibandingkan dengan laki-laki. Perempuan begitu tersubordinasi dibawah laki-laki, namun seiring berkembangnya era, ide-ide baru dan muncul kaum-kaum intelektual yang sadar akan isu perempuan dapat 
Jurnal SOSIO DIALEKTIKA 6 (2) (2021)

P-ISSN: 2540.8941 e-ISSN: 2623.2944

e-mail; sosiodialektika@unwahas.ac.id

doi; http://dx.doi.org/10.31942/sd.v6i2.5680
Dinamika Pertumbuhan Feminisme Di China Dalam Perspektif Konstruktivisme

menggeser pemikiran-pemikiran tradisional atas peranan perempuan dalam keluarga dan masyarakat melalui gagasan femnisme itu sendiri.

Perubahan tersebut bisa dilihat dalam tiga aspek, yaitu pertama, kemunculan feminisme di China muncul karena msuknya gagasan atau ideide yang dibawa oleh bangsa barat setelah terjadinya Perang Candu (opium war) pada abad ke-19 era Dinasti Qing berkuasa. Lalu munculnya tokoh feminisme He Zhen sebagai norm entrepreneurs atau agen yang memiliki gagasan tentang adanya ketidaksetaraan perempuan di China. Kedua, adanya pengaruh rativikasi CEDAW tahun 1979 dan Beijing Platform for Action 1995 terhadap perubahan kebijakan serta perundang-undangan mengenai kesetaraan gender di China. Ketiga, feminisme telah melembaga dengan adanya bukti meningkatnya partisipasi perempuan dibidang politik, ekonomi dan pendidikan.

\section{DAFTAR PUSTAKA}

Baker, H.D.R. 1979. Chinese Family and Kinship. New York: Columbia University Press.

Beijing Platform for Action. (1995). Beijing Platform for Action. Canadian Woman Studies.

Berry, C., \& Sang, T. D. (2004). The Emerging Lesbian: Female Same-Sex Desire in Modern China. Comparative Literature. https://doi.org/10.2307/4125391

Bowen, G. A. (2009). Document analysis as a qualitative research method. Qualitative Research Journal. https://doi.org/10.3316/QRJ0902027

Brown, K. (2012). The communist party of China and ideology. In China: An International Journal. https://doi.org/10.1353/chn.2012.0013

Bryson, V. (2019). Feminism. In Contemporary Political Ideologies. https://doi.org/10.4324/9780429038839-9

Chamberlain, H. B., \& Meisner, M. (1987). Mao's China and After: A History of the People's Republic. Pacific Affairs. https://doi.org/10.2307/2758836

Chang, M. H. (1996). The Thought of Deng Xiaoping. Communist and PostCommunist Studies. https://doi.org/10.1016/S0967-067X(96)80022-5

China MOE. (2010). Outline of China's National Plan for Medium and Long-term Education Reform and Development. Development.

Cho, S. Y. (2014). International Women's Convention, Democracy, and Gender 
Jurnal SOSIO DIALEKTIKA 6 (2) (2021)

P-ISSN: 2540.8941 e-ISSN: 2623.2944

e-mail; sosiodialektika@unwahas.ac.id

doi; http://dx.doi.org/10.31942/sd.v6i2.5680
Dinamika Pertumbuhan Feminisme Di China Dalam Perspektif Konstruktivisme

Equality. Social Science Quarterly. https://doi.org/10.1111/ssqu.12069

Creswell, J. W. (2007). Research Design: Qualitative, Quantitative and Mixed Method Aproaches. SAGE Publications. https://doi.org/10.4135/9781849208956

Croll, E. (2013). Feminism and socialism in China. In Feminism and Socialism in China. https://doi.org/10.4324/9780203123140

Englehart, N. A., \& Miller, M. K. (2014). The CEDAW Effect: International Law's Impact on Women's Rights. Journal of Human Rights. https://doi.org/10.1080/14754835.2013.824274

Fennell, V. L. (2009). Mao Zedong (1893-1976). In The International Encyclopedia of Revolution and Protest. https://doi.org/10.1002/9781405198073.wbierp0965

Gao, B. (2015). the birth of Chinese feminism: essential texts in transnational theory. Feminist Review. https://doi.org/10.1057/fr.2015.8

Gardam, J. (1998). Women, human rights and international humanitarian law. International Review of the Red Cross. https://doi.org/10.1017/s0020860400091221

Haiping, Y. (2006). Chinese women writers and the feminist imagination, 19051948. In Chinese Women Writers and the Feminist Imagination, 1905-1948. https://doi.org/10.4324/9780203086391

Howell, J. (2002). Women's Political Participation in China: Struggling to Hold Up Half the Sky. In Parliamentary Affairs. https://doi.org/10.1093/parlij/55.1.43

Hu, G., Baker, S. P., \& Baker, T. D. (2010). Urban-rural disparities in injury mortality in China, 2006. Journal of Rural Health. https://doi.org/10.1111/j.1748-0361.2009.00255.x

Jones, N., \& Presler-Marshall, E. (2012). Governance and poverty eradication: Applying a gender and social institutions perspective. Public Administration and Development. https://doi.org/10.1002/pad.1618

Knechtges, D. R., Hsü, I. C. Y., \& Hsu, I. C. Y. (1977). The Rise of Modern China. Journal of the American Oriental Society. https://doi.org/10.2307/600863

Lasiyo, L. (2018). PENGARUH BUDDHISME TERHADAP NEOKONFUSIANISME DI CINA. Jurnal Filsafat. https://doi.org/10.22146/jf.32215

Marlow, E. (2018). The Opium Wars. In Jazz in China. https://doi.org/10.2307/j.ctv5jxp24.6

210 Anna Yulia Hartati ${ }^{1,2}$, Ismiyatun ${ }^{3}$, Adi Joko Purwanto ${ }^{4}$, Nur Islamiati 
Jurnal SOSIO DIALEKTIKA 6 (2) (2021)

P-ISSN: 2540.8941 e-ISSN: 2623.2944

e-mail; sosiodialektika@unwahas.ac.id doi; http://dx.doi.org/10.31942/sd.v6i2.5680
Dinamika Pertumbuhan Feminisme Di China Dalam Perspektif Konstruktivisme

Morishima, M. (1982). Why has Japan 'succeeded'? In Why has Japan 'succeeded'? https://doi.org/10.1017/cbo9780511582455

Moser, C., \& Moser, A. (2005). Gender mainstreaming since Beijing: A review of success and limitations in international institutions. In Gender and Development. https://doi.org/10.1080/13552070512331332283

Naughton, B. (1993). Deng xiaoping: The economist. The China Quarterly. https://doi.org/10.1017/S0305741000013886

O’Brien, J., \& Gemelli, M. C. (2012). United Nations Decade for Women. In Encyclopedia of Gender and Society. https://doi.org/10.4135/9781412964517.n433

OECD. (2016). Education in China - A Snapshot. Oecd.

Pieke, F. N. (2012). The Communist Party and social management in China. China Information. https://doi.org/10.1177/0920203X12442864

Platform, B., \& Island, P. (2009). Beijing + 15 : Review Literature And Arts Of The Americas.

Roces, M. (2010). Women's Movements in Asia. In Women's Movements in Asia. https://doi.org/10.4324/9780203851234

Selden, M., \& Perry, E. J. (2010). Chinese society: Change, conflict and resistance. In Chinese society: Change, conflict and resistance. https://doi.org/10.4324/9780203856314

Shalev, C. (2001). China to CEDAW: An update on population policy. Human Rights Quarterly. https://doi.org/10.1353/hrq.2001.0011

Shambaugh, D. (1993). Deng xiaoping: The politician. The China Quarterly. https://doi.org/10.1017/S0305741000013874

Silverman, D. (2004). Qualitative Research: Theory, Method and Practice. In Qualitative Research.

SS., S. S. (2015). Regional-global Governance Network on Women's Rights: CEDAW and its Implementation in ASEAN Countries. Procedia - Social and Behavioral Sciences. https://doi.org/10.1016/j.sbspro.2015.01.397

The United Nations. (1995). Beijing declaration and platform for action. In Fourth World Conference on Women.

Tryggestad, T. L. (2014). State feminism going global: Norway on the United Nations Peacebuilding Commission. Cooperation and Conflict. https://doi.org/10.1177/0010836714530576

United Nations. (1995). Beijing declaration and platform for action. In Fourth 
Jurnal SOSIO DIALEKTIKA 6 (2) (2021)

P-ISSN: 2540.8941 e-ISSN: 2623.2944

e-mail; sosiodialektika@unwahas.ac.id

doi; http://dx.doi.org/10.31942/sd.v6i2.5680
Dinamika Pertumbuhan Feminisme Di China Dalam Perspektif Konstruktivisme

World Conference on Women.

Wang, B., \& Driscoll, C. (2019). Chinese feminists on social media: articulating different voices, building strategic alliances. Continuum. https://doi.org/10.1080/10304312.2018.1532492

Weigelin-Schwiedrzik, S. (2012). Deng Xiaoping and the transformation of China. In Pacific Affairs. https://doi.org/10.5509/2012851169

Wu, A. X., \& Dong, Y. (2019). What is made-in-China feminism(s)? Gender discontent and class friction in post-socialist China. Critical Asian Studies. https://doi.org/10.1080/14672715.2019.1656538

Xiaoqi, D. (1991). Feminism in China. Asian Studies Review. https://doi.org/10.1080/03147539108712752

Yifei, S. (2011). China in the "Post-Patriarchal Era." Chinese Sociology \& Anthropology. https://doi.org/10.2753/csa0009-4625430401

Zheng, J. (2016). New feminism in China: Young middle-class chinese women in Shanghai. In New Feminism in China: Young Middle-Class Chinese Women in Shanghai. https://doi.org/10.1007/978-981-10-0777-4

Zheng, W. (1997). Maoism, Feminism, and the UN Conference on Women: Women's Studies Research in Contemporary China. Journal of Women's History. https://doi.org/10.1353/jowh.2010.0239

Zheng, W. (2016). " State Feminism "? Gender and Socialist State Formation in Maoist China Author ( $s$ ): Wang Zheng Published by: Feminist Studies , Inc . Stable URL: http://www.jstor.org/stable/20459044 REFERENCES Linked references are available on JSTOR for this articl. 31(3), 519-551.

https://www.bbc.com/indonesia/dunia-51763849, diakses tanggal 06 Nopember 2020“Document 9: A ChinaFile Translation”. www.chinafile.com/document-9-chinafile-translation. Diakses pada tanggal 06 Nopember 2020, pukul 15.00 wib 